\title{
Kosmopolitisme \\ og postnationalisme i \\ nyere norsk litteratur
}

\section{Dybt under bølgerne}

I Øyvind Rimbereids Solaris korrigert (2004) befinder vi os i et vestnorsk landskab i år 2480. Fortælleren i digtet har gulsort grease på hænderne og er formand for 123 robotarbejdere. De opererer i lange tunneller under havet i Nordsøen, mellem boreplatformsvrag og tomme gasbrønde. Sproget i digtet er en blanding af dialekt fra Stavanger-egnen og mundtlig engelsk, men også med indslag af tysk og norrønt, måske også lidt dansk. Det er præget af bortfaldne vokaler og forkortelser, og af at de særegne skandinaviske bogstaver æ, $\varnothing$ og å ikke er i brug. Det lyder sådan her:

6 I natt dei i slammen

Arbeider, miner greipmaskinar,

Dept undr bolgjerne

Undr siddybridgen,

Self-organising repairing hydropipes

Vid deirs simpl 8-funktionkroppar.

DEI er 123 stk., miner robot-

Arbeideren. 123 x 8 x algoritm

Er deirs breyn.

DEIRS kollectiven

Breyn er abstract

Og exist onli millom dei,

Som millom A og B

Or som millom ein odder human og aig

Ven wi spiik.

Rimbereids sproglige sci-fi er et direkte udtryk for den hybridisering, som er en følge af international kontakt i den mest globaliserede virksomhed i Norge, olieudvinding på kontinentalsoklen. Det er bemærkelsesværdigt, at udgangspunktet for den sprog- 
lige nyskabelse ikke er officielt norsk skriftsprog, men et lokalt eller regionalt talesprog. Med et konkret sprogligt greb fremstiller Rimbereid på den måde ikke blot en typisk norsk regionalisme (som også findes hos ham), men også en pointe i nyere kosmopolitisk teori: sammenknytningen af det lokale og det globale i et nært skæbnefællesskab - kombineret med en svækkelse af det nationale. Kosmopolitisme og postnationalisme er vigtige træk ved samfundsudvikling i de sidste tyve år, og det er ingen tilfældighed, at det geografiske landskab, hvor Rimbereids kulturelle kosmopolitisme udspiller sig, er Stavanger-regionen. Stavanger blev allerede i 1970'erne hovedsæde for udvinding af olie, og Norge har siden da været et senmoderne minedriftssamfund. Den store økonomiske vækst og velstandsudviklingen i Norge beror på olie- og gasboring på havet, og denne virksomhed var helt fra starten i udpræget grad international, både industrielt, økonomisk og forskningsmæssigt. Olieudvindingens historiske dimensioner danner grundlaget for beskrivelsen af dagens Norge i Jan Kjærstads store trilogi om kosmopolitten Jonas Wergeland. Kjærstads opfattelse af Norge i senmoderniteten er, at det moderne Norge er et lykketræf.

Denne artikel skal handle om kosmopolitiske og postnationale aspekter ved nyere norsk litteratur, repræsenteret ved et eksemplarisk værk, nemlig Dag Solstads Armand V. Fotnoter til en uutgravd roman (2006). I denne sammenhæng er det ikke urimeligt at begynde med at minde om olieudvindingens underlige historie i Norge. Det er den, som mere end noget andet har gjort Norge til en del af det globaliserede samfund. Fortælleren i Kjærstads roman Forføreren, Kamela Warma, udlægger historien således: "Nationaliseringen' af havet og havbunden er den mest radikale omfordeling af geografiske områder og økonomiske goder siden kolonitiden”. Hun uddyber det ved at påpege, at "hvad angår geografisk størrelse, ligger Norge cirka på 60. plads i verden. Hvis man derimod inkluderer det havområde som nu er kommet under norsk herredømme, er der pludselig kun 11 lande, som er større end Norge." (Kjærstad [1993] 2006, p. 48) Kjærstad gengiver den pinlige historie om Norges Geologiske Undersøgelser, som i 1958 fik en henvendelse fra Udenrigsministeriet vedrørende mulige erhvervsinteresser på kontinentalsoklen og skrev tilbage, at "man kan se bort fra muligheden af, at der skulle findes kul, olie eller svovl på kontinentalsoklen langs den norske kyst." Dette brev hænger i dag i glas og ramme på oliemuseet i Stavanger. Få år senere dukkede et par amerikanere op, som bad om koncession til at foretage prøveboringer ud for den norske kyst. Da begyndte eventyret.

Der var to forhold, som særligt bidrog til den økonomiske succeshistorie. For det første: Da råderetten over soklen skulle fastlægges, fik Norge aftaler med både England og Danmark om at følge et midterlinjeprincip, noget som slet ikke var en selvfølge. Dermed endte det kolossale Ekofisk-felt på norske hænder. For det andet: Norge etablerede en koncessionsordning, som på lang sigt skaffede samfundet enorme indtægter. Danmark valgte en anden løsning. Først kom man dårligt ud af forhandlingerne med både Norge og Tyskland. Dernæst solgte man simpelthen rettighederne til A. P. Møller for en periode på 50 år (Kindingstad og Hagemann 2002, p. 20). Det er muligt, at Kjærstad har ret i, at olieeventyret beror på et lykketræf. Men lige netop på dette punkt handlede man fremtidsrettet i forhold til den globaliserede $\varnothing$ konomi, som blev ved med at udvikle sig. For den traditionelle nationalstat 
var den største trussel at blive invaderet af en fremmed magt. I det postnationale samfund, hvor økonomien er globaliseret, er den største trussel, at de transnationale selskaber trækker sig ud af landet og ikke vil investere. Der er en intens konkurrence om tilgang af skatteindtægter og investeringer fra store internationale selskaber. Uden en rimelig andel af den globale kapitalismes midler er det vanskeligt at opretholde de vestlige velfærdssamfund. I den forstand har Norge været et globaliseret samfund siden begyndelsen af 1970'erne. Og i norsk litteratur er Jan Kjærstad en af de forfattere, der har bragt sådanne perspektiver klarest ind i sine tekster.

\section{Kosmopolitisme}

"Locality itself is a historical product," skriver Arjun Appadurai i Modernity at Large (1996), "the histories through which localities emerge are eventually subject to the dynamics of the global" (Appadurai, p. 18). Rimbereids region og olieudvindingen er et eksempel på dette. "Global facts take local form." I Solaris korrigert skildrer forfatteren en af de historiske årsager, som har bidraget til at skabe den senmoderne lokalitet "olielandet". Både Rimbereid og Kjærstad er eksempler på nyere norsk litteratur med et fremtrædende kosmopolitisk perspektiv i kombination med et kritisk blik på nutidens samfund.

Dette er i overensstemmelse med kosmopolitisk teori. Kosmopolitisme kan dateres helt tilbage til kynikerne i det 4. århundrede f.Kr. Det er her, vi finder udtrykket "borger af kosmos". Filosoffen Kwame Anthony Appiah bemærker i bogen Cosmopolitanism. Ethics in a World of Strangers (2006):

4f The formulation was meant to be paradoxical, and reflected the general Cynic skepticism toward custom and tradition. A citizen - a polites - belonged to a particular polis, a city to which he or she owed loyalty. The cosmos referred to the world, not in the sense of the earth, but in the sense of the universe. Talk of cosmopolitanism originally signaled then, a rejection of the conventional view that every civilized person belonged to a community among communities. (Appiah 2006, p. xvi)

Robert Fine og Robin Cohen hævder i bogen Conceiving Cosmopolitanism: Theory, Context, and Practice (2002), at historien har "four cosmopolitan moments". ${ }^{.}$Stoikerne repræsenterer det første med deres teori (i forlængelse af kynikerne) om en dobbelt stedsbestemmelse; menneskene er både borgere af polis og af kosmos (Vertovec \& Cohen 2002, p. 137 ff). Kant repræsenterer det andet historiske moment med sine politiske teorier om en "verdensborgerlig tilstand" og forestillingene om en tredje retsinstans i tillæg til statsretten og folkeretten, nemlig de verdensborgerlige rettigheder. Disse teorier blev fremført i skrifter som "Ideen zu einer allgemeinen Geschichte in weltbürgerlicher Absicht" fra 1784 og Zum ewigen Frieden fra 1795. Det tredje historiske moment knytter Fine og Cohen til Hannah Arendt, og det refererer direkte til brevvekslingen mellem hende og Karl Jaspers om forbrydelserne mod menneskeheden under Den Anden Verdenskrig. Et lige så naturligt valg kunnet have været Menneskerettighedserklæringen fra 1948, som på sin vis realiserer Kants tanker om en ny retsinstans. Det fjerde historiske moment i Fines og Cohens 
fremstilling er vor egen tid. En fornyet interesse for kosmopolitisme er opblomstret i de seneste ti år, både i filosofisk og sociologisk teori. Fine og Cohen knytter denne udvikling til Martha Nussbaum, et valg som virker lidt underligt, i al fald fra et europæisk perspektiv. I München har Ulrich Beck ledet et større projekt med begrebet kosmopolitisme som konvergenspunkt for en omfattende beskrivelse af særkender ved det, han kalder "den anden modernitet", det senmoderne, globaliserede samfund. Siden sit indflydelsesrige værk Risikogesellschaft fra 1986 har Beck udgivet en hel trilogi om vor tids kosmopolitisme; Macht und Gegenmacht im globalen Zeitalter (2002), Der kosmopolitische Blick (2004) og Das kosmopolitische Europa (2004, sammen med Edgar Grande).

En hovedpointe for Beck er forskellen mellem globalisme og kosmopolitisme. Globaliseringsbegrebet er annekteret af den økonomisk dominerede samfundsbeskrivelse og handler om nyliberalisme og kapitalens og arbejdskraftens frie bevægelighed. Kosmopolitisme er et multidimensionalt begreb, som omfatter både $\varnothing$ konomiske, politiske, kulturelle og institutionelle perspektiver. Kosmopolitisme er blevet selve definitionen på en ny epoke, hævder Beck, den refleksive modernitet. Det drejer sig om en irreversibel ændring, som medfører genforhandling af det nationale, blandt andet i lyset af betydningen af mangfoldige loyaliteter, transnationale liv og moderne stedspolygami. Beck skelner mellem en filosofisk, normativ kosmopolitisme, f.eks. repræsenteret ved Kant, og hvad han kalder reelt eksisterende kosmopolitisme. ${ }^{2}$ Kosmopolitisme er ikke bare en (kontroversiel) idé, men er blevet en realitet. En konsekvens er, at det, som Beck kalder den "metodologiske nationalisme" i samfundsfag og humanistiske fag, må nedbrydes. Metodisk nationalisme indebærer bl.a., at man i faglige sammenhænge betragter nationen som den naturlige "beholder" for fagenes indhold, noget som har forhindret nødvendige perspektiveringer. Med "det kosmopolitiske blik" vil Beck betone en ny faglig holdning. Denne holdning indebærer et "melangeprincip": "den sammensatte forbindelse mellem lokale, regionale, nationale og kosmopolitiske kulturer". ${ }^{3}$

\section{Postnationale konstellationer}

Sammenfattende kan man sige, at den reelt eksisterende kosmopolitisme fremtvinges af en ny postnational konstellation. Det første element i den postnationale konstellation er det nye risikosamfund, som Beck beskriver i Risikogesellschaft. Mens moderniseringen i det 19. århundrede opløste det statiske, standsbaserede bondesamfund og skabte grundlag for industrisamfundet, opløser moderniseringen i dag industrisamfundet, hævder Beck. ${ }^{4}$ Efter Tjernobyl er det blevet klart, mener Beck, at det, som er sket, medfører "ophøret af 'de andre', ophøret af alle vores raffinerede distanceringsmuligheder." ${ }^{\prime} \mathrm{N} ø \mathrm{~d}$ kan man ignorere, men ikke atomalderens trusler. Den globaliserende tendens fra vor tids nye trusler består i, at verden ikke længere har gemmesteder. I risikosamfundet er vi udleveret til en fælles, global skæbne, uanset hvor på kloden vi bor. Det første moderne defineres ved kollektive livsmønstre, fuld beskæftigelse, nationalstatslig organisering af økonomien, udelukkelse af kvinder fra arbejdsmarkedet, intakte kernefamilier, territorielle organisationsformer, samt formålsrettet udnyttelse af naturen. ${ }^{6}$ Det andet moderne er defineret af 
økologiske kriser, øget arbejdsløshed, individualisering, begyndende globalisering af kønsrevolutionen, reduktion af kernefamiliens betydning og af klassesamfundets strukturer og afnationalisering af atomtruslen. En hovedpointe er, at ingen af vor tids største risikoudfordringer lader sig løse ud fra et nationalt perspektiv.

Det andet element i den postnationale konstellation er den globaliserede kapitalisme - som olieindustrien er den vigtigste eksponent for i Norge. Multinationale koncerner flytter kapital, arbejde og produktion til de dele af verden, hvor lønsomheden er størst, uafhængigt af nationale grænser. Og virksomhederne tilhører dem, som investerer i dem, hedder det. Tilknytning, ansvar og forpligtelser over for et lokalmiljø eller en nation reduceres. Erhvervslivet og den multinationale kapitalisme skal ikke kun forholde sig til arbejdere og ejere, som den traditionelle kapitalisme skulle, men i endnu højere grad til forbrugerne. Og selv om også arbejdsstyrken i stadig højere grad bliver internationaliseret gennem arbejdsmigration, er forbrugerne i endnu større udstrækning en globaliseret størrelse. Forbrugersamfundet er et verdenssamfund. Den globale kapitalisme og det senmoderne forbrugersamfund har skabt et nyt politisk spil, hvor den traditionelle, territorielle nationalstat har mistet meget af sin magt og mulighed for styring.

Det tredje element i den postnationale konstellation er globaliseringen af civilsamfundet. Denne proces har en lang historie. Menneskerettighedserklæringen fra 1948 etablerede forestillingen om, at det enkelte individ besidder ukrænkelige rettigheder vis-à-vis en hvilken som helst stat og uafhængigt af enhver form for partikulær identitet. Denne grundtanke har været med til at danne grundlag for udviklingen af et globaliseret civilsamfund, først og fremmest udtrykt gennem FN-systemet og det internationale perspektiv. Men også gennem ikke-statslige organisationer er det globale civilsamfund vokset frem. Det er det, Beck kalder institutionaliseret kosmopolitisme. Traditionelle internationale bevægelser som arbejderbevægelsen og kvindebevægelsen har i nyere tid fået følge af et stort antal organisationer og sammenslutninger, som repræsenterer en postnational konstellation i udviklingen af en ny global offentlighed omkring spørgsmål som menneskerettigheder, miljøbeskyttelse og international solidaritet. På flere af disse felter er det korrekt at hævde, at det internationale civilsamfund repræsenterer en reel kosmopolitisk modmagt, der har sat dagsordenen og været afgørende for i det hele taget at få de traditionelle politiske eliter og nationalstaterne til at sætte prekære spørgsmål på dagsordenen. En af årsagerne til, at denne udvikling har kunnet finde sted, er de nye verdensomspændende medier. Et vigtigt element i det globaliserede civilsamfund er det, Beck kalder kosmopolitisk empati. Mens den første modernitet var præget af en national territorialisme, bryder den anden modernitet med "enten-eller-teorien om identitet", som Beck kalder den. Der sker en globalisering af følelser. Der er i den senmoderne verden en beredvillighed både med hensyn til empati og handling uafhængigt af sted. Denne beredvillighed har mange humanitære konsekvenser i forbindelse med kriser, ulykker og katastrofer. Efter afviklingen af den kolde krig har den imidlertid også fået vidtrækkende militære konsekvenser i form af såkaldte "humanitære interventioner" eller postnationale krige. Såvel Norge som Danmark er for tiden dybt involveret i sådanne krige. 
Det fjerde element i den postnationale konstellation har også en lang historie, nemlig globaliseringen af kultur. Jeg tænker da ikke bare på massekulturens og populærkulturens spredning gennem moderne medier eller på den "worlding" af kunst og litteratur, som kunstfagene og de såkaldte elitenationer skaber gennem deres egne kulturinstitutioner. Globaliseringen af kultur er måske stærkest eksemplificeret gennem de såkaldte verdensreligioner, hvor global udbredelse ofte er en eksplicit målsætning. Politiske bevægelser som imperialisme, kommunisme og fascisme har også haft globale udbredelsesintentioner. I dag er religiøst begrundet terrorisme en betydningsfuld postnational konstellation. Også hollywoodisering og mcdonaldisering er vigtige elementer i en vedvarende globalisering af kultur, sammen med sproglig anglificering og udbredelse af musik, mode og film.

Lige så interessant er imidlertid den spredning af og hybridisering af kulturer, som i dag finder sted som følge af øget migration og større kontakt mellem kulturer på grund af rejser og ny kommunikation. Inden for litteraturen er det ikke mindst påfaldende, hvordan fornyelse har fundet sted gennem kulturmøder, kulturkontakt og kulturkonfrontation. Man behøver blot at nævne forfattere som Salman Rushdie og V. S. Naipaul.

I nyere norsk litteratur bliver kosmopolitiske og postnationale perspektiver berørt i en række romaner af forfattere fra flere generationer, som f.eks. Dag Solstad og Anja Breien, Jan Kjærstad, Thure Erik Lund, Øyvind Rimbereid og Sigmund Jensen. I det følgende skal opmærksomheden rettes mod sådanne perspektiver i Dag Solstads Armand $V .^{7}$

\section{Solstad og den lave nationale identitet}

I Dag Solstads seneste roman Armand $V$ møder vi en norsk topdiplomat og hans søn. Sønnen beslutter sig for en militær karriere og rejser ud for at gøre tjeneste i internationale missioner. Han bliver såret og kommer blind hjem. Faren, diplomaten, gør sig ingen overvejelser i forbindelse med sønnens valg ud over, at det repræsenterer en protesthandling mod ham selv. Han tænker, at han reagerede fejlagtigt, da sønnen fortalte ham, at han ville være soldat. Denne generations-narcissistiske tankegang - som får sønnens valg af livsbane til helt og holdent at handle om ham selv, om faren - dækker over det faktum, at sønnen foretager sit valg i en ny verdenssituation, en postnational konstellation, hvor "humanitære interventioner", dvs. postnational krig, har afløst både modernitetens traditionelle nationale forsvar og kolonialismens imperialisme.

Den norske topdiplomat i Solstads roman har det, fortælleren kalder "lav national identitet" (p. 122). En diplomat uden adækvat national identitet synes at svare til romanens form; den er "uudgravet". Den består kun af fodnoter til en ikke realiseret roman. Den lave nationale identitet ser imidlertid ikke ud til at have noget med en postmoderne afnationalisering at gøre. I al fald ikke i første omgang. Det drejer sig først og fremmest om politisk servilitet over for stormagten USA. Lav national identitet ser ikke ud til at betyde postnational nationalisme, ikke en national identitet som "passer" til vor tid, men en beklagelig mangel på national identitet som har den konsekvens, at Norge foretager et politisk knæfald for USA. På den måde 


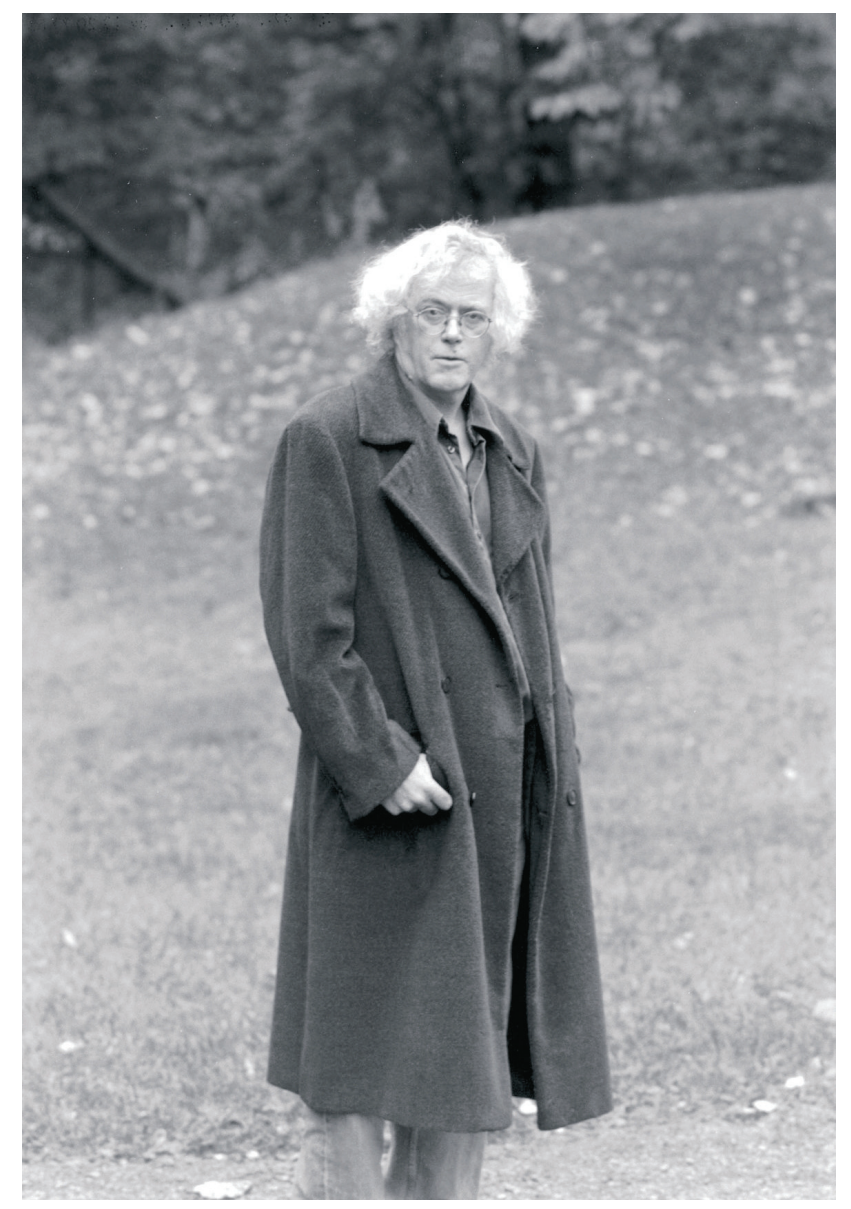

kan romanen langt hen ad vejen siges at repræsentere en velkendt og forudsigelig kritik af USA. Umiddelbart siger dette måske ikke så meget om en ændring af nationalitetsforestillingerne i vor tid.

I norske historiefremstillinger bliver der ofte lagt vægt på, at nationsopfattelsen og nationsbegrebet er en folkeligt forankret størrelse. Der var ganske vist en intellektuel elite - Wergeland, P. A. Munch, Bjørnson, Asbjørnsen og Moe, Sophus Bugge m.fl. - som bidrog til at fremelske norsk national identitet, men det var bondestanden, som blev fremstillet som den bærende klasse i forestillingerne om det norske. Det er ikke så ofte, perspektivet bliver vendt på hovedet. Det er den "folkelige nation," nordmændene dyrker, den som er forankret i folkelig kultur og græsrodsbevægelser.

Solstads perspektiv er anderledes. I den forstand er det moderne. Han anlægger delvist et urbant, intellektuelt perspektiv, delvist et "government-perspective" (som officiel repræsentant for nationen). Hos Solstad består den individuelle spænding $\mathrm{i}$, at Armand ikke fuldt ud kan identificere sig med det, han repræsenterer. I og for sig er en sådan situation det normale i offentligheden. Armand er da også helt tilpas med situationen - lige til han i mødet med den amerikanske ambassadør når til en afgørende erkendelse. Så befinder han sig pludselig i en eksistentiel klemme.

Før vi kommer så langt som til mødet med USAs ambassadør og det eksistentielle dilemma, må vi se lidt på ambassadørrollen, "the government perspective" 


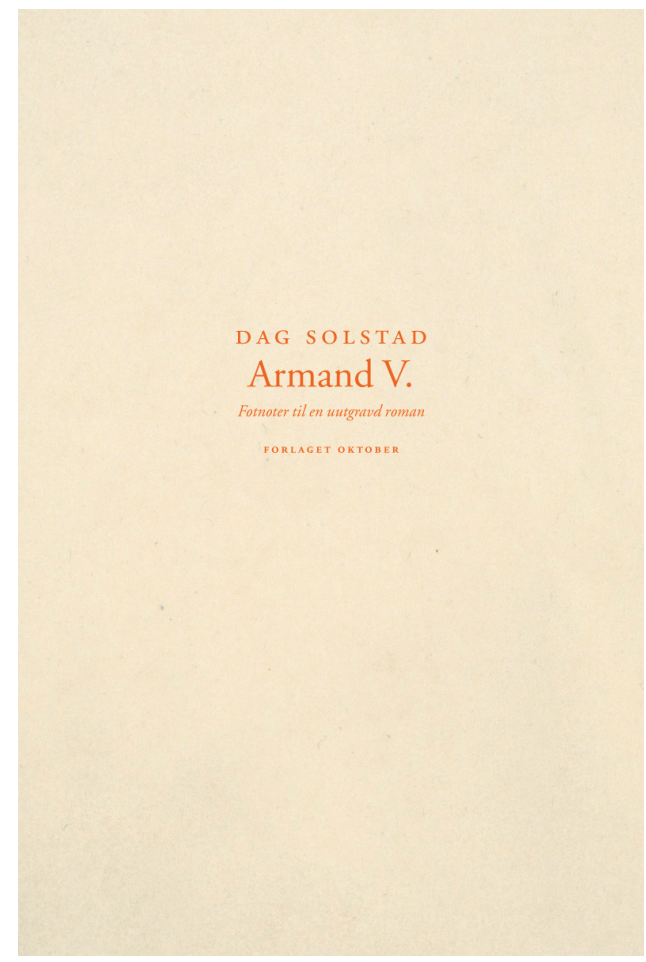

og den "lave nationale identitet". Hvorfor har Solstad valgt en ambassadør som sin hovedperson?

Moderne diplomati bliver ofte ført tilbage til bystaterne i renæssancens Norditalien. Den første magt, som i dag er en nationalstat, som udsendte en permanent repræsentation, var Spanien. Ambassadøren blev en del af The Court of England i 1487. Fra slutningen af 1500-tallet begyndte denne praksis at blive udbredt. Diplomatiet er altså meget ældre end den moderne nationalstat. Oprindeligt var der et hierarki blandt diplomater afhængigt af, om de repræsenterede kongedømmer, grevskaber, fyrstedømmer eller republikker. Republikkerne var lavest rangeret. Systemet spredte sig fra Vesteuropa til Rusland og Østeuropa. Efter Wiener-kongressen i 1815 efter Napoleons fald blev der grundlagt et internationalt system for diplomatiet, corps diplomatique. (Historien ser anderledes ud i andre verdensdele.) Set i et historisk perspektiv kan man måske sige, at diplomatiet - ved siden af handlen, opdagelserne, rejseaktiviteten og kolonialismen - er blandt de tidligste og mest udbredte kosmopolitiske og internationale fænomener. Diplomatiet blev forholdsvist tidligt en institution, som havde kosmopolitiske eller internationale målsætninger. Diplomatiet er en officiel samfundsinstitution, som specifikt har til opgave at få forholdet mellem en hjemlig magt og andre magter til at fungere. Det kosmopolitiske tema må derfor også inkludere diplomatiet. Ud over hos Solstad berøres det i norsk litteratur også af Jan Kjærstad. ${ }^{8}$

I sin bog om Nations and Nationalism since 1780 (1990) skriver Eric Hobsbawm i kapitlet "The government perspective" om fremvæksten af den moderne nationalstat og om dens mødepunkter med sine borgere. I sin tidlige fase havde den forholdsvis løse koblingspunkter, men selv familier, som boede langt fra statens centrale institutioner, mødte nationalstaten gennem postbuddet, politiet eller sko- 
lelæreren, gennem folk som havde med jernbanen at gøre, foruden gennem militæret. Man kan dertil lægge fogeden og skattevæsenet. Efter nationalstatens tilblivelse $\emptyset$ gedes antallet af ansatte betragteligt i institutioner, hvor den enkelte person mødte magthaverne. Nationens statsadministration var den største erhvervsgruppe blandt de erhverv, der krævede læse- og skrivefærdigheder. I lande med statskirker udgjorde kirken også en vigtig institution, hvor borgerne mødte staten.

I kraft af demokratiseringen, som fandt sted inden for nationalstaten, blev det mere og mere vigtigt for nationalstaten at udvikle en national identitet hos den enkelte, sådan at loyaliteten svarede til samfundets behov. Integration og fællesskabsfølelse blev mere og mere afgørende for, at nationen kunne fungere - og fungere forudsigeligt. Blandt de vigtigste loyaliteter, som måtte sikres, var villigheden til at betale skat (til fordel for nation og fællesskab) og villigheden til at ofre liv og helbred i militærtjeneste i tilfælde af krig og ydre trusler. Traditionelt har nationalstaten især brugt uddannelsessystemet og kirken til at sikre den nødvendige nationale identitet og loyalitet, samt forskellige kulturprojekter, der skaber integration og fællesskabsfølelse.

Som følge af sekulariseringen har kirke og religion fået en mindre national rolle. Skole og uddannelsessystem har til gengæld fået en stadig stigende betydning. I senmoderniteten, dvs. efter afviklingen af den kolde krig, har også forsvaret fået en både ny og øget betydning.

I Dag Solstads roman spiller netop militæret og uddannelsessystemet en afgørende rolle. Den generation Solstad tilhører - og som Armand også er en del af - er den første generation i Norge, som havde adgang til højere uddannelse uafhængigt af familiebaggrund og forældrenes $\varnothing$ konomi (som følge af oprettelsen af Statens Lånekasse for Utdanning). Denne generation blev forældregenerationen til den postmoderne generation, som skulle bemande et helt nyt postnationalt forsvar, som ikke blot havde nationalstatslige forsvarsopgaver, men som skulle deltage i internationale missioner på fremmed jord langt borte, missioner, der var begrundet i en ny internationalisme eller kosmopolitisme.

Are, Armands søn, deltager i en "humanitær intervention", som Ulrich Beck hævder er en konsekvens af "kosmopolitisk empati". Armand forholder sig altså stærkt negativt - for ikke at sige uforstående - til en sådan deltagelse. Han er selv 68 'er og et produkt af 60'ernes masseuddannelse til det moderne efterkrigs-Norges vækst- og velstandssamfund, hvor olieudvinding, de nye computere og rumfarten blev tidens symboler. Armand og Are repræsenterer to tider: den kolde krigs vækstog velstandsregime baseret på masseuddannelse - og den postmoderne eller postnationale tid, hvor loyaliteten ikke kun er vendt mod nationalstaten og villigheden til at tjene den økonomisk og militært, men også mod et større, internationalt fællesskab. Armand opfatter ikke sønnen således. Den tanke, at Are har en postnational eller kosmopolitiske loyalitet - som altså omfatter "humanitære interventioner" - eksisterer ikke som en mulighed i farens forestillingsverden. Mulighederne for en ny kosmopolitisme, hvor forsvaret som institution har fået en ny funktion, løsrevet fra nationalstaten, er altså fremmed for topdiplomaten. Det er ikke blot det, at faren er politisk uenig i sønnens valg. Han opfatter det overhovedet ikke som en politisk handling, men som en privat, familiær psykologisk - og temmelig umoden - reaktion. Sønnen tillægges ingen politisk bevidsthed. 
Der er altså en nærmest fuldstændig splittelse mellem generationerne, mellem moderniteten og postmoderniteten, mellem den "lave nationale identitet" og en postnational politik i romanen. Dette svarer til en bemærkelsesværdig emotionel afstand mellem far og søn. Den vender vi tilbage til. Først må vi tage fat på et andet bemærkelsesværdigt afstandsfænomen, nemlig mellem det teknologiske moderniseringsniveau i romanen og i Armands liv på den ene side og samtiden på den anden side. Lad os tage udgangspunkt i den uddannelse, Armands generation får ved Universitetet i Oslo. Armand selv er filolog og vil gerne være historiker. I øvrigt er han særlig interesseret i seriøs, europæiske film. Det uddannelsesmiljø, som er skildret mest indgående, er imidlertid det matematisk-naturvidenskabelige miljø. På norsk hedder de studerende i sådanne fag "realister". Realisterne på Blindern fremstilles ganske vist som uambitiøse og kedelige. De vil være lærere - ikke pionerer i forskning og erhvervsliv. Men det er den moderne verdens teknologi, de taler om og beundrer. De er "konforme studenter", men de "beundrer og lovpriser de teknologiske bedrifter som har fundet sted i vor tid, og som de ved vil komme" (p. 84). Med en "poetisk inderlighed udråbte studenterne deres hyldest til deres egen tid og de enorme muligheder" (p. 83). Blandt de teknologier og muligheder, som fremhæves, er olieeventyret, rumfarten og computeren. Det er teknologiske felter, som i 1960'erne så absolut var mulighedernes land. Forfatteren skriver om dem i 2006, så det er en historisk gestus, som skal til for at gå tilbage og projicere dette som fremtid. "Om computerens konstruerede hjerne, som vil forårsage en revolution, som vil overgå alt," skriver forfatteren, efter denne revolution har fundet sted. Ligeledes: "Jagten på de uddrivelsesværdige forekomster af sort guld, som skal forandre Norge," (p. 83) skriver forfatteren, efter denne forandring har fundet sted. Det er det moderne velfærds-Norge, som projiceres ud i fremtiden - i datid.

Dette moderne teknologiske tema bliver imidlertid sat i perspektiv af det teknologiske moderniseringsniveau i skildringen af samtidens begivenheder i fortællingen. Ét er, at en topdiplomat i Norge anno 2006 kommer gående til en enke på Majorstuen og betaler husleje med rede penge og får kvitteret huslejebogen. Det repræsenterer et teknologisk moderniseringsniveau som - i bedste fald - svarer til studentens liv i 1960'erne. Selv da han er udstationeret som Norges ambassadør i Storbritannien, kommer Armand gående og ringer på hos damen for at betale kontant. Mere opsigtsvækkende er dog fraværet af andre postmoderne teknologier som for eksempel mobiltelefonen. Allerede i romanens begyndelse kommer Armand hjem til sin lejlighed flere dage før end varslet. Lejligheden har han udlånt til sønnen. Det er da, han ser det, som han opfatter så fornedrende for sønnen - og som åbenbart minder ham om noget. Men hvorfor kommer han hjem på denne måde: Hvorfor har han ikke taget mobiltelefonen og givet besked til sønnen? Eller sendt en SMS i det mindste. Senere får vi at høre, at han - en travl diplomat - flere gange begiver sig af sted fra Skillebekk til Majorstuen for at opsøge sønnen. Hvorfor ringer han ikke på mobilen til sønnen for at forhøre sig, om han er hjemme? Armand synes teknologisk set simpelthen ikke at leve i sin egen tid. Og han skal være en af Norges fremmeste diplomater. Armand V fremstår som en person uden kontakt med den postmoderne virkelighed. Det er ikke bare de postnationale militære operationer - 
og holdningen bag dem - han ikke synes at begribe. Han lever også teknologisk i en anden tid end sin egen samtid.

Blandt Hobsbawms opremsede elementer, som repræsenterer mødepunkter mellem stat og borger i tidligere tider, var jernbanen. "The nineteenth-century revolution in transport and communications typified by the railway and the telegraph tightened and routinized the links between central authority and its remotest outposts", siger Hobsbawm (Hobsbawm, p. 81). Den moderne udgave af transport er flyet, og det sammenbinder ikke blot nationens centrum og forposter, men i lige så høj grad nationen og omverden. I al fald gælder det for landets internationale hovedlufthavn - som spiller en central rolle i Armand V. Dette motiv berører Armand kun indirekte via ungdomsvennen Paul Buer. Til gengæld spiller Paul Buer en vigtig, selvstændig rolle i romanen. Dele af fortællingen er fortalt med Buer som synsvinkelbærer. Det antydes af den "egentlige" roman, at teksten "deroppe" måske har en anden hovedperson end i fodnoteromanen. Buer er en nærliggende kandidat. Det bliver også antydet i teksten, at romanen om Buer muligvis bliver den næste roman, forfatteren skal skrive - hvis han tør. Anmeldere har taget Solstad på ordet her og sagt, at de tror, Solstad her varsler sin næste bog - ligesom de mener, han har gjort det i sine senere udgivelser. Som skæbne, som kompleks romanperson, er Paul Buer måske en lige så fascinerende skikkelse som Armand V.

Og hans skæbne er direkte knyttet til et politisk spil omkring beslutningen om at lægge Norges nye hovedlufthavn ved Gardermoen - frem for Hurum og Hobbøl. På sin vis kan vi sige, at romanen har en udenrigspolitisk og en indenrigspolitisk akse. Den udenrigspolitiske er knyttet til ambassadørskikkelsen, filologen Armand V - og Norges deltagelse i militære operationer i udlandet er det hovedemne, som trækkes ind i romanen. Den indenrigspolitiske akse er knyttet til meterologskikkelsen, realisten Paul Buer - hovedtemaet, som trækkes ind, er lufthavnen ved Gardermoen. Begge de inddragne akser indeholder en fortælling med tragisk udgang: Armands søn bliver såret og ender som blind; Buer dør under tragiske omstændigheder pga., hvad han opfatter som ureglementerede indspil i det politiske spil omkring vedtagelsen af lufthavnens placering.

Norges internationale hovedlufthavn er både konkret og allegorisk stedet, hvor nationens forhold til verden har vigtige (teknologiske) forudsætninger. At de politiske processer omkring anlæggelsen af lufthavnen er inficeret af uredelighed, urent spil og usandheder, kan allegorisk læses som en alvorlig mangel eller tegn på falskhed i nationens forhold til det internationale. Paul Buer er en ibsensk Brandskikkelse som ikke kan leve med fejhed, falskhed og usandhed - som ikke kan gå på akkord med sin personlige sandhed. Man kan også betragte ham som en moderniseret dr. Stockmann. Og som med Ibsens figurer går det ham dårligt.

Det er sandsynligt, at forbilledet for Paul Buer er Jan Wiborg, som blev fundet nøgen og død i en baggård på et hotel i København dagen før, han skulle fremlægge beviser for, at rapportens opmålinger var blevet manipuleret. Der blev iværksat en politiefterforskning. Hurum-tilhængerne frygtede, at Wiborg var blevet myrdet. Andre mente, Wiborg havde begået selvmord. Han havde alvorlige personlige problemer, og det barske spil om valg af placeringen af Norges hovedlufthavn gjorde ikke hans helbredssituation bedre. Der er både blevet skrevet og lavet dokumentar- 
program om Wiborgs sag, hvor flere tvivlsomme forhold og ubesvarede spørgsmål bliver belyst.

I Solstads romantekst handler det mest om skæbnen for en ibsensk figur - og om den allegoriske betydning, som opstår ved, at Norges centrale kontaktzone med udlandet er politisk inficeret. Buer og Armand er meget forskellige figurer, og de takler deres sandhedsproblem - eller autenticitetsproblem - ganske forskelligt. Buer kan ikke klare "spillets" udfordringer vis-à-vis den personlige sandhed. Armand kan fint klare spillet. Han er kynisk - det er ikke en hemmelighed for nogen - men han er loyal og tjener sit land. Han har et velfungerende forhold til diskrepansen mellem det private og det offentlige.

Måske er grunden til, at dette fungerer så godt, et meget distanceret følelsesliv eller: måske er hans distancerede forhold en konsekvens af spillet. Her er det ikke så let at afgøre, hvad der er årsag og virkning. Det afgørende er, hvordan man vurderer fortælleren og hans position - inklusive hans følelsesmæssige involvering.

Det er påfaldende, hvor distanceret Armands "nære relationer" fremstilles. I sin ungdom har han et erotisk eventyr med sin tilkommende kones tvillingesøster, et eventyr som har kraft nok til at bevare en fascination hele livet. Men til trods for en lang opbygning af spænding frem mod dette møde (brug af rejse, udsættelse osv.) lyder det, da de endelig går i seng sammen: han "fuldførte sin gerning" (p. 99). Ingen skal kunne anklage Solstad for at være en erotisk forfatter.

Også forholdet til sønnen, for ikke at tale om den næsten fraværende datter, er skildret som følelsesmæssigt ganske distanceret - til trods for at sønnen spiller en meget central rolle i fortællingen. De er uden kontakt i mange måneder ad gangen. Og de mødes ofte "tilfældigt" i forbindelse med, at Armand betaler huslejen.

Men Armand engagerer sig intensivt i sønnens skæbne efter ulykken. Og forholdet til tvillingesøsteren varer ved. Blot to gange får vi at vide, at han mister kontrollen over sin distancerede holdning til mennesker og meninger. Første gang er, da han giver sønnen sin uforbeholdne mening i forbindelse med, at han vil være elitesoldat. Anden gang er på toilettet, hvor han ser den amerikanske ambassadørs "sande ansigt." I fodnote 75 står der om episoden, hvor faren "mister besindelsen" over for sønnen (p. 181n). Der står at han "valgte at miste besindelsen" - en form for "oxymoron" eller et paradoks, at han valgte at "fremstå som den, han var, knægtens far" (p. 181). "Han var den, han var.” I romanen er han sig selv nærmest for første gang - og følgerne er tragiske. Diplomaten burde måske have fortsat med at være "diplomatisk" - også over for sønnen. Autenticitet fremstår ikke som noget eftertragtet - tværtimod: oprigtighed og sandhed er farlig for sønnen og for Paul Buer. "Han ofrede sønnen," står der (p. 184). Her dukker Brand-motivet således op igen (og Brand bygger på den bibelske historie om Isak og sønnen). Den anden gang, Armand mister sin distance, er det ham selv, det går ud over. Han ser den amerikanske ambassadørs sande ansigt, magtens sande ansigt - og det gør det umuligt for ham at fortsætte sit dobbeltspil over for sit eget land. Dag Solstads tematisering af kosmopolitiske perspektiver og postnationale konstellationer ser altså ud til at munde ud i en uforsonlig og absolut afvisning af USA's magtposition. 


\section{Stærk produktion af egne picts}

Dag Solstads Armand $V$ viser nogle udvalgte kosmopolitiske og postnationale problemstillinger og dramatiserer disse bl.a. i et far-søn-motiv, hvor det moderne og det postmoderne mødes. En række andre romaner i nyere norsk litteratur udfylder og uddyber tematiseringen af dette felt. I Jan Kjærstads store romanværk fra 1990'erne, trilogien om Jonas Wergeland, følger skildringerne et kosmopolitisk system: Det hjemlige spejler det internationale - og vice versa. Systemet kommer programmatisk til udtryk på følgende vis: "De har Ganges [...] Vi har Sognefjorden. Den er vores hellige flod" (Kjærstad 1999, p. 459). På denne måde findes der et "glokalt" perspektiv i Kjærstads værk. Det globale og det lokale danner en sammenhæng eller udgør (i al fald retorisk) et system. Systemet er imidlertid ikke komplet med disse to dele. Romanserien handler nemlig først og fremmest om Norge. Den har et nationalt anliggende. Systemet har dermed tre dele, ikke blot to: det lokale - Grorud; det nationale - Norge; og det globale eller internationale. Det appliceres i værket på følgende vis: Handling, episoder og konkrete hændelser udspiller sig konsekvent på Grorud og ude i den store verden. Men det refleksive niveau, det niveau hvor der generaliseres, historiseres, pædagogiseres og dannes teorier, er næsten konsekvent nationalt. Kjærstad iværksætter altså på den side Ulrich Becks "melange"-princip: Det lokale, det globale og det nationale hører sammen og danner en fleksibel, ubefæstet og ikke-cementeret, men reelt eksisterende konstellation. Det er det, nogle samfundsforskere i dag kalder en kosmopolitisk realitet. Samtidig opretholder Kjærstad det, som repræsenterer kosmopolitismens modsætning, nemlig en "metodologisk nationalisme" - dvs. at nationen og det nationale betragtes som den naturlige "beholder" for indsigt, kundskab, fakta og erfaring. Hos Kjærstad er der samtidig et kosmopolitisk blik og en national optik.

I Anja Breiens "billedfortælling" Kaniaw (2006) drejer det sig om kosmopolitisme i nutidens Oslo, om kultur og kommunikation i en dramatisk fortælling, som udspiller sig i Oslo og Kurdistan. Bogen handler om kulturmøder og kulturkonflikter, om at kommunikere på tværs af generationer og kulturer - og om at kommunikere de nye kulturfortællinger i et nyt kunstnerisk sprog. Vi møder Kaniaw, en kurdisk pige som er stukket af fra sin egen familie i Oslo, fordi hun nægter at lade sig tvangsgifte med sønnen til en ven af faren. Hun er nemlig kæreste med norske Dag. Det drejer sig altså om den slags historier, som vi kender fra hverdagen eller medierne i Norge. Men Kaniaw vil ikke blot flygte fra familien og gemme sig i en anden by. Hun vil gøre tingene ordentligt. Hun rejser alene til en fjern landsby i Kurdistan for at opsøge den mand, hendes far har lovet hende bort til. Hun vil selv fortælle ham, hvorfor der ikke kan blive noget ægteskab. Det er en farlig rejse, hun begiver sig ud på. For at kunne gennemføre den, må hun skifte identitet og rejse som norsk journalist. Hun bleger sit hår og bærer blå kontaktlinser. Hun har et kamera med for at spille journalistrollen overbevisende. Og hun giver 40 billeder til en norsk kvinde, som hun tilfældigt træffer i Damaskus.

Denne kvinde er så bogens fortæller. Hun er filminstruktør til filmfestival i Damaskus - og ligner bogens forfatter meget. Bogen fortælles ved hjælp af de 40 billeder, men det fremgår af teksten, at fortælleren har rejst den samme rute som Kaniaw for at blive i stand til at fortælle hendes historie, noget som indikerer, at hun er 
stærkt berørt af hendes skæbne. Kaniaw måtte krydse mange grænser på sin rejse, geografiske grænser, men lige så ofte kulturelle grænser. Kaniaw bliver Maria for at kunne håndtere sin kulturkonflikt, og hun bliver i Anja Breiens fortælling den hybridfigur eller det postkoloniale subjekt, hun er tvunget til at være, på grund af sin position midt imellem det kurdiske og det norske. Breiens bog er en enkel, klar fortælling uden dikkedarer. Den handler om en påtrængende kosmopolitisk empati, om den afterritorialisering af solidaritet og indlevelse, som er stadigt stigende i det senmoderne samfund. Fjerne begivenheder trænger ind i vores hverdag via medierne og ændrer vores følelsesliv.

I Thure Erik Lunds roman Inn (2006) skildres en forvandling eller et identitetsskifte fra et liv i "denne uhyrlige indestængte nationalistiske verden" til "at blive kosmopolit" (Lund, p. 12). Ingen af de centrale begreber i disse formuleringer gives imidlertid stabil mening i romanen. De flyder mellem forskellige intellektuelle og følelsesmæssige positioner i takt med det skrivende jegs mentale bevægelser, mellem alvor og ironi, tilslutning og sarkasme, ligegyldighed og desperation. Hovedpersonen opfatter sig ved romanens begyndelse som døende på grund af en kræftsvulst på ryggen. Dette motiv træder dog i baggrunden lidt efter lidt, og jeget genopstår tilsyneladende, tager et nyt navn og afventer nye identitetspapirer. Han deltager også i en karnevalistisk forvandlingsfestival som "strohgestalt" i Tyskland. Han mister sine gamle venner fra den lokal hjembygd og finder med tiden nye bekendtskaber i Amsterdam, hvor han har taget ophold. Hovedpersonen er - i og for sig både før og efter sin påståede forvandling - først og fremmest en klanløs, som de fleste af Lunds figurer. De klanløse kritiseres allerede af Homer. Meticer, ikke-borgere, blev betragtet som frie, men ikke som en integreret del af fællesskabet, og de, som ikke hørte hjemme i samfundet, var ikke blot uden fast tilknytning; de blev også betragtet som lovløse og hjerteløse (Vertivec \& Cohen, p. 5). Thure Erik Lunds hovedperson har som livsprojekt "at give pokker", han bryder op, rejser, forandrer sig, men genopstår ikke som en tydelig identitet. Hovedpersonen i Inn bliver bogstavelig talt det, han hele tiden har været på vej mod mentalt, en klanløs, en tilflyttet udlænding i Amsterdam, en ikke-borger. Der finder han et fællesskab uden for fællesskabet. Homers kritik af meticerne, de tilflyttede udlændinge, står i et paradoksalt forhold til hans store helt Odysseus, som frem for nogen anden er en rejsende i fremmede lande. Også i Inn spiller rejsen en helt central rolle: "Når man står der med dagen foran sig, så ser man tydeligt, at alt er rejser" (Lund, p. 42). Lunds hovedperson er en klanløs kosmopolit, en eksistentiel outsider og en tydelig modsætning til Solstads eliteperson, diplomaten Armand.

Disse glimt fra andre nyere norske tekster er kun ment som eksempler på, at kosmopolitisme og postnationalisme har en relativ stor udbredelse i litteraturen. Forfatterne forholder sig til forskellige aspekter ved det komplekse fænomen, og det vil være urimeligt at komme med konklusioner her på baggrund af et udvalgt eksempel. I sin fulde rækkevidde betragtes samtidens kosmopolitisme: 1) som en ny politik fra venstrefløjen, dvs. som en middelvej mellem etnocentrisk nationalisme og partikularistisk multikulturalisme; 2) som en vision for et globalt demokrati og et muligt verdensborgerskab; 3) som begrundelse for en ikke-essentialistisk, post- 
identitetspolitik med udgangspunkt i overlappende interesser og en hybrid offentlighed med den hensigt at udfordre traditionelle opfattelser af tilhørsforhold og identitet; 4) som en deskriptiv term for sociokulturelle processer eller individuel adfærd, værdier eller dispositioner, som manifester evnen til at engagere sig i kulturel mangfoldighed (Vertovec \& Cohen, p. 1). Skønlitteraturen forholder sig naturligvis ikke normativt eller programmatisk til sådanne problemstillinger, men inkluderer flere af dem i fortællinger om vor tid, typisk på en afsøgende, kritisk, tvetydig og ambivalent facon. Men det er tydeligt, at selv de forfattere, som påtager sig at se allerlængst ud i fremtiden, som f.eks. Øyvind Rimbereid, forestiller sig, at litteraturens lidt skæve blik vil blive ved med at følge os. Selv i det fremtidige, globaliserede "olieland" vil kunstneren blive ved med at give sit billede af samfundet:

\section{KONKLUTION: Aig haf ein litl}

Defect i venstr phantomic breyn-

Bark, ein noko for sterk production

Af eigne picts

Oversat af Mads Rosendahl Thomsen.

\section{Noter}

I David Held opererer med tre hovedfaser i sin fremstilling: stoikerne, Kant og samtiden. Se "Principles of cosmopolitan order" i Gillian Brock and Harry Brighouse (red.): The Political Philosophy of Cosmopolitanism, p. $10 \mathrm{ff}$.

2 Han er slet ikke alene om at skelne sådan. Man finder det hos flere kosmopolitismeteoretikere, bl. a. hos Scott L. Malcomsen i artiklen "The Varieties of Cosmopolitan Experience" i Pheng Chea \& Bruce Robins.

3 I denne artikel er "beholderen" norsk. Det skyldes, at dette temanummer skulle handle om norsk litteratur. Artiklen indgår imidlertid i et forskningsprojekt, "Kosmopolitisme, postnasjonalisme og det kulturelle selv i nyere litteratur og kultur", hvor perspektivet er internationalt. (Se også note 7).

4 Beck (1997), p. 16.

5 Op. cit., p. 9.

6 Beck: Macht und Gegenmacht im globalen Zeitalter, pp. 79 og 81.

7 I det ovenfor nævnte forskningsprojekt vil følgende værker blive analyseret: V. S. Naipaul: Half a Life, Marios Vargas Llosa: Hablador, Milan Kundera: L'Ignorance, Jonas Hassen Khemiri: Montecore: en unik tiger, Katrine Marie Guldager: Kilimanjaro, Jens Christian Grøndahl: Piazza Bucarest, Dag Solstad: Armand V, Jan Kjærstad: Wergeland-trilogien, Anja Breien: Kaniaw.

8 Se Jan Kjærstad: Wergeland-trilogien.

\section{Litteratur}

Appadurai, Arjun: Modernity at Large. Cultural Dimensions of Globalization, Minneapolis \& London: University of Minnesota Press, 1996. 
Appian, Kwame Anthony: Cosmopolitanism. Ethics in a World of Strangers, London: Allen Lane, 2006.

Beck, Ulrich \& Edgar Grande: Das kosmopolitische Europa, Frankfurt am Main: Suhrkamp, 2004.

Beck, Ulrich: Macht und Gegenmacht im globalen Zeitalter, Frankfurt am Main: Suhrkamp, 2002.

Beck, Ulrich: Der kosmopolitische Blick, Frankfurt am Main: Suhrkamp, 2004.

Breien, Anja: Kaniaw. En bildefortelling, Oslo: April Forlag, 2006.

Brock, Gillian and Harry Brighouse (red.): The Political Philosophy of Cosmopolitanism, Cambridge: Cambridge University Press, 2005.

Chea, Pheng \& Bruce Robbins (red.): Cosmopolitics. Thinking and Feeling beyond the Nation, Minneapolis \& London: University of Minnesota Press, 1998.

Hobsbawm, Eric: Nations and Nationalism sice 1780, Cambridge: Cambridge University Press, 1990.

Kjærstad, Jan: Forføreren, Oslo: Aschehoug, 2006 [1993].

Kjærstad, Jan: Oppdageren, Oslo: Aschehoug, 2006.

Lund, Thure Erik: Inn, Oslo: Aschehoug, 2006.

Rimbereid, Øyvind: Seine topografiar, Trådreiser, Solaris korrigert, Oslo: Gyldendal, 2005.

Solstad, Dag: Armand V. Fotnoter til en uutgravd roman, Oslo: Oktober, 2006.

Vertovec, Steven \& Robin Cohen (red.): Conceiving Cosmopolitanism. Theory, Context, and Practice, Oxford: Oxford University Press, 2002. 